\title{
Plankton or benthos: where krill belongs in Spitsbergen fjords? (Svalbard Archipelago, Arctic)
}

\author{
Kajetan Deja ${ }^{1}\left[\right.$ D Mateusz Ormańczyk ${ }^{1} \cdot$ Katarzyna Dragańska-Deja ${ }^{1}$
}

Received: 25 September 2018 / Revised: 12 June 2019 / Accepted: 18 June 2019 / Published online: 10 July 2019

(c) The Author(s) 2019

\begin{abstract}
This study couples observations of krill (Thysanoessa inermis, Thysanoessa longicaudata, Thysanoessa rashii) from Tucker trawl nets and cameras, trying to test hypothesis that in the glaciated fjords of Svalbard most of the euphausiids biomass is located in near-bottom habitat and explains why in this region there are a substantial part of the krill population near the sea floor. Photographic material from the summers of 2013-2017 shows large numbers of near-bottom euphausiids (39\% of the total krill biomass in Hornsund and $41 \%$ in Kongsfjorden), which reached a maximum density of $751 \pm 224$ indiv. $\mathrm{m}^{-3}$ in Kongsfjorden, $731 \pm 198$ indiv. $\mathrm{m}^{-3}$ in Hornsund, and $426 \pm 124$ indiv. $\mathrm{m}^{-3}$ in Adventfjorden. Regional distribution of near-bottom aggregations of krill seem to be associated with close proximity to the glacier front rather than with depth. The highest densities were located in the glacial bays. Where and why these aggregations occur is probably complicated and dependent on many environmental factors acting together. However, the dominant factors seem to be sedimentation and estuarine circulation. No krill aggregations were found during the winter cruise. The dominating species was T. inermis which made up $90 \%$ of the community. Other krill species-T. rashii and T. longicaudata, made up $6 \%$ and $4 \%$, respectively. In the summer, aggregations of other macrozooplankton were also observed: amphipods of the genus Themisto and chaetognaths of the genera Eukrohnia and Parasagitta. Euphausiid densities in the water column (from Tucker trawl hauls) were an order of magnitude lower ( 0.33 indiv. $\mathrm{m}^{-3}$ for Kongsfjorden and 0.61 indiv. $\mathrm{m}^{-3}$ for Hornsund) than those of the near-bottom aggregations observed on cameras system. At most stations, the krill exhibited a behaviour, known as "nose diving" in the sediment, which is likely related to feeding. Observation of this phenomenon may indicate that krill (mostly T. inermis), found near the bottom of Spitsbergen fjords, is looking for food there. Near-bottom aggregations of zooplankton, mainly krill, are common in glacial bays and can be important in the function of the fjord ecosystem. Our research proves that the zooplankton biomass can be highly underestimated if only Tucker trawl sampling is done, due to neglecting the near-bottom layer in this type of method.
\end{abstract}

Keywords Arctic $\cdot$ Fjords $\cdot$ Spitsbergen $\cdot$ Plankton $\cdot$ Benthos $\cdot$ Krill

\section{Introduction}

Krill (the collective name of Euphausiacea species) is a key component of many marine ecosystems. Additionally, krill is an important link between microscopic algae

Electronic supplementary material The online version of this article (https://doi.org/10.1007/s00300-019-02524-1) contains supplementary material, which is available to authorized users.

Kajetan Deja

kajetandeja@iopan.gda.pl

1 Institute of Oceanology of the Polish Academy of Science, Sopot, Poland (microplankton) and large predators such as whales, seabirds, and fish (Cleary et al. 2012). Globally, there are 86 species of krill (Everson 2000); in the fjords of Spitsbergen, there are five. The most common is Thysanoessa inermis, followed by also numerous Thysanoessa rashii and Thysanoessa longicaudata. In connection with the intensification of Atlantic water inflow, species Meganyctiphanes norvegica and Nematoscelis megalops are increasingly noted in Arctic region (Buchholz and Buchholz 2010). Many species of krill are known to form dense pelagic swarms and schools in temperate and polar seas, mostly in the euphotic zone, and near the sea surface or close to the sea ice (Mauchline and Fisher 1969). There has been a recent increase in the number of publications on benthopelagic krill aggregations due to the 
development of new techniques that use underwater imagery and hydroacoustics (Hirche et al. 2016). Benthopelagic aggregations of krill were discovered in both the Northern Hemisphere (Greene et al. 1988; Gomez-Gutierrez and Robinson 2006; Laudien and Orchard 2012; Hirai and Jones 2012; Hirche et al. 2016) and the Southern Hemisphere (Gutt and Siegel 1994; Clarke and Tyler 2008; Nicol and Brierley 2010). Antarctic krill (Euphausia superba) were found near the seafloor at depths up to $3500 \mathrm{~m}$ (Clarke and Tyler 2008; Schmidt et al. 2011). A multitude of observations of krill near the bottom of the ocean, especially at great depths, indicate that these are not accidental observations of "ecological outliers" (Brierley 2008). Deep migration and feeding at the sea bottom is probably an important part of the ecology of krill, and this characteristic constitutes a link between the benthic and pelagic food webs. However, occasionally epizotic parasitoid infection cause large numbers of individuals descend to die, resulting in mass mortalities (Gómez-Gutiérrez et al. 2003). The depth data showing near-bottom concentrations of $M$. norvegica presented by Hirai and Jones (2012) suggest that these aggregations may be an important source of nutrients and carbon for the deepliving pelagic and benthic fauna in deep sea environment. Schmidt et al. (2011) showed that local differences in the vertical distribution (lower concentration of krill in surface waters) of Antarctic krill could indicate less efficient food acquisition or higher predator pressure in surface waters. Due to their frequent change of feeding location (from the seabed to the upper water column and back), krill can provide considerable amounts of labile iron to the surface waters of the Southern Ocean (Schmidt et al. 2011) and this process might also occur in the Spitsbergen fjords.

The observations of benthopelagic aggregations of euphausiids in Kongsfjorden (Hirche et al. 2016), Hornsund, and Adventfjorden (this study) support the hypothesis of the wider nature of this phenomenon, as well as the need for a new assessment of the impact of a benthopelagic community on the fjord ecosystem. Our aim was to determine which habitat retains most of the krill biomass in glacial fjordsthe water column or the near-bottom waters and explain why in this region there are a substantial part of the krill population near the sea floor. A combination of two sampling approaches-Tucker trawl net and near-bottom inspection with camera, let us evaluate adequate methodologies for study densities of zooplankton in Spitsbergen fjords.

\section{Study area}

The study area in the West Spitsbergen fjords is at high latitude (above $77^{\circ} \mathrm{N}$ ) but is considered sub-Arctic due to frequent exposure to warm North Atlantic water inflows (Cottier et al. 2005, 2016; Promińska et al. 2017). The examined fjords have different morphologies, Kongsfjorden is a deep fjord (more than $300 \mathrm{~m}$ at the entrance) connected to the outer shelf and has easy advection of shelf waters, while Hornsund is shallower ( $<200 \mathrm{~m}$ at the entrance) and usually filled with colder coastal waters (Drewnik et al. 2016; Promińska et al. 2017). Isfjorden, on the other hand, is a large fjord system with several branches. One of the branches is Advendfjorden which is approximately $8 \mathrm{~km}$ long and $3.5 \mathrm{~km}$ wide. Both Isfjorden and Adventfjorden are exposed to Atlantic water advection because they have no sill in the fjord mouth. Glaciers are present in the innermost fjord basins and the meltwater discharge is responsible for the strong summer density stratification and resulting estuarine circulation (Promińska et al. 2017). The water exchange in these fjords might be very dynamic (Jakacki et al. 2017) due to the tidal currents, wind-driven advection from the shelf (Goszczko et al. 2018), and glacial outflow (Urbanski et al. 2017). The following water masses were separated on the basis of CTD data (IOPAN, unpublished data) collected during our study in the fjords: Atlantic Waters (salinity above 35 , temperature above $2.5^{\circ} \mathrm{C}$ ), Local Coastal Waters (salinity around 34-35, temperature between 2.5 and $0{ }^{\circ} \mathrm{C}$ ), Winter Cooled Waters (salinity above 35 , temperature below $0{ }^{\circ} \mathrm{C}$ ), and Surface Coastal Waters (salinity below 34 and temperature above $0{ }^{\circ} \mathrm{C}$ ). Characteristics distinguishing individual water masses in the Arctic fjords have been taken from the literature noted above.

\section{Material and methods}

The data presented here were collected between 2013 and 2017 during summer cruises (daylight) each year on S/Y Oceania and one winter cruise (only darkness) in 2016 on R/V Helmer Hanssen. There were 107 photographic stations established in the fjords of western Spitsbergen, mainly in Hornsund and Kongsfjorden (Fig. 1, Online Resource 1), and there were a total of 52 horizontal stratified Tucker trawl hauls conducted in the summer seasons of 2014, 2015, and 2016 for both fjords combined (Fig. 1, Online Resource 2). Photographic data were collected with three different systems depending on what was available on each cruise. In 2013, photographic stations were sampled using a lander equipped with a DSLR camera. The lander took ten digital photos per station. Most photographic data (2014-2017) were collected using an underwater camera, referred to here as a drop camera. This consisted of an analogue camera with a resolution of $700 \mathrm{TV}$ lines (TVL) for live view and a digital camera (Panasonic HX-A500) that recorded material at high resolution $(1280 \times 720 \mathrm{px})$ on a memory card. The device was towed for $10 \mathrm{~min}$ above the bottom at a speed of $0.1-0.2$ knots $(0.05-0.1 \mathrm{~m} / \mathrm{s})$. For both types of gear, a pair of lasers was used to determine scale in the images. At some stations in 2016, the film material was collected using 

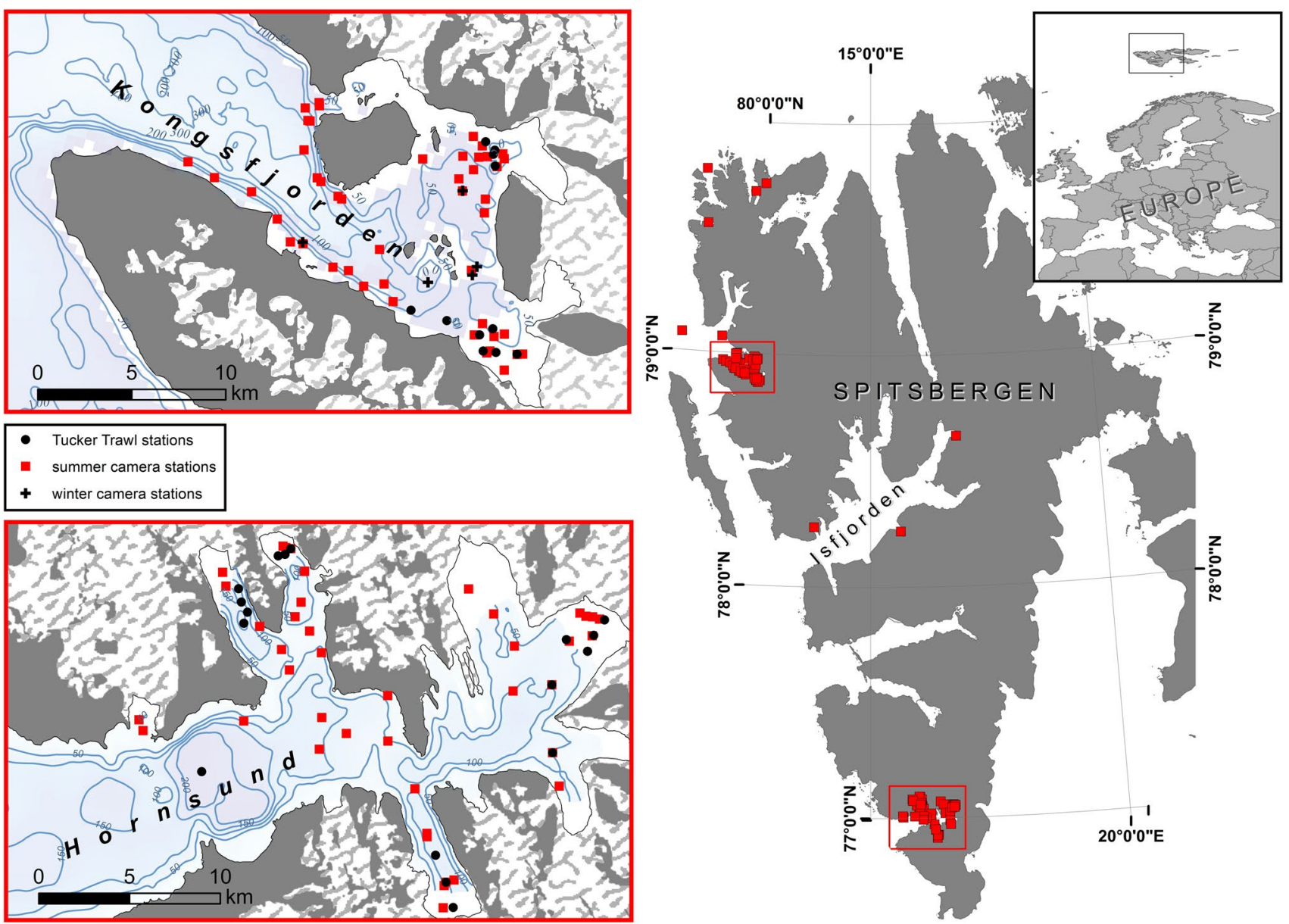

Fig. 1 Location of stations where seabed photos and Tucker trawl hauls were collected

a camera mounted on an epibenthic sledge (Online Resource 1). The camera used here is the same as in the case of drop cameras. None of the instruments were equipped with a pressure sensor. The camera on the lander was mounted one metre above a special weight, which released the trigger mechanism of the camera at the moment of contact with the bottom. This system worked well in hard bottom environments and in areas where the sediments were relatively well compacted. Soft, poorly compacted deposits, characteristic for glacier bays and the inner part of the fjord, mostly prevented the application of this method, because the process caused resuspension of the sediment and resulted in poor or null visibility. To minimize the chance of this happening with the drop camera, it was towed approximately $50 \mathrm{~cm}$ above the bottom. At stations located near the glacier front, this distance was $10-20 \mathrm{~cm}$ due to very poor visibility caused by high concentration of suspended particular matter from glacier discharge. Estimates of the height of the device over the bottom were supported by comparison with objects of known size in the images, e.g. sponges and sea anemones. Other researchers have used a similar method to assess the height of the camera above the bottom (Gutt and Siegel 1994; Hirche et al. 2016). To calculate the number of individual krill at a station, five snapshots were selected from each video transect (drop camera) and five photos in the case of the lander. Snapshots and photos were selected from the beginning, middle, and end of the station recording and the average number of krill from all five counts was taken for further analysis. This method reduces the phototaxy effect, since the counts from the beginning of the recording, where krill did not have time to react, are also taken to the average. Following Gutt and Siegel (1994), the volume of water in which counts were made (number of individuals was expressed in $\mathrm{m}^{3}$ ) was calculated using the known geometry of the camera lens and the distance to the bottom which is known. The density values from the video material are presented in six intervals: $(0 ; 1-10 ; 11-50 ; 51-150 ; 151-350$; and $\geq 350$ indiv. $\mathrm{m}^{-3}$ ).

The Tucker trawl had an opening of $1 \mathrm{~m}^{2}$ and $1 \mathrm{~mm}$ mesh size. It was hauled horizontally for $10 \mathrm{~min}$ at an average speed of 1.5 knots $(0.8 \mathrm{~m} / \mathrm{s})$. At each station, there was a surface haul $(20-0 \mathrm{~m})$ and a bottom haul (approximately 
$5 \mathrm{~m}$ above the bottom) (Fig. 1). The samples were preserved in $4 \%$ formaldehyde and analysed in the laboratory a few months later. All organisms from a subsample were counted, weighted, and identified, and these data were converted to the volume of the whole sample. All of the samples were georeferenced and labelled with the depth, date, and basic environmental parameters (e.g. temperature, salinity, and sediment/bottom type). The taxonomy nomenclature was adopted from WoRMS (https://www. marinespecies.org/).

CTD profiles were collected from the bottom to the surface on all cruises and the water mass types were classified based on the information in the literature (Promińska et al. 2017).

To visualize the area of interest and the distribution of the near-bottom krill aggregations, GIS analyses were performed using ArcGIS 10.4 software. Coastline and glacier were digitized from Landsat 8 satellite data from 2015. Near-bottom abundance estimations for whole fjords are based on the following assumptions: near-bottom aggregation of krill does not occur in areas shallower than $25 \mathrm{~m}$ and this krill aggregation occupies 1-m layers of water above the bottom. On the basis of bathymetric data (www. iopan.gda.pl/projects/Visual/index.html) for both fjords, areas with depths $<25 \mathrm{~m}$ were not taken into account in the analysis, and the unknown bathymetry near the glacier front was extrapolated using the inverse distance weighted (IDW) interpolation method. Near-bottom krill concentrations from measurement points were interpolated (kriging ordinary method) into the remaining area of the fjord (Fig. 4). After interpolation, data were divided into five density classes (polygons): $0,1-10,11-50,51-150$, and 150-300 (indiv. $\mathrm{m}^{-3}$ ). The water volume near the bottom ( $1 \mathrm{~m}$ layer) assigned to individual classes was calculated. To determine the krill density, the central value for each interval was selected $\left(0,5,30,100\right.$, and 200 (indiv. $\left.\mathrm{m}^{-3}\right)$, respectively), and the krill density was calculated for the individual polygons. The biomass for the studied area was calculated using a wet weight of $79.5 \mathrm{mg}$ for individual krill. This weight was calculated as weighted arithmetic mean of the wet mass obtained for each Tucker trawl stations for each species separately. A weight to each species corresponding to its percentage was assigned: Thysanoessa inermis - 0.9, Thysanoessa longicaudata -0.04 , Thysanoessa rashii- 0.06 . The results from all examined polygons were summed to obtain an estimated krill biomass in the entire fjord near-bottom area for depths $>25 \mathrm{~m}$. The krill concentration in the water column was calculated based on the average krill density obtained from the Tucker trawl data and the calculated volume of each fjord. GIS analyses were performed according to methods described in the ArcGIS Help Library (https://resources. arcgis.com/).

\section{Results}

Photographic material was examined from 107 photo stations (Fig. 1). Krill densities exceeding 100 indiv. $\mathrm{m}^{-3}$ were recorded at ten stations, with the largest numbers at the KGF9 station $\left(751 \pm 224\right.$ indiv. $\left.\mathrm{m}^{-3}\right)$ and at the HSD10 station (731 \pm 198 indiv. $\mathrm{m}^{-3}$ ) (Fig. 2). Krill aggregations with $>100$ individuals $\mathrm{m}^{-3}$ were recorded at five stations in Kongsfjorden (KGF 2, KGF 34, KGF 44, KGF 46, KGF 9), four stations in Hornsund (HSD 1, HSD 1', HSD 10, HSD 7), and at one station in Isfjorden (ISF 1) which should be interpreted as "cohesive swarms", i.e. swarms that are several dozen metres in diameter and contain several tons of biomass (Kalinowski and Witek 1980; Miller and Hampton 1990). The most abundant species dominating euphausiid community was T. inermis which made up $90 \%$ of it. Other krill species-T. rashii and $T$. longicaudata made up $6 \%$ and $4 \%$ of total krill abundance, respectively. In our study, an aggregation of chaetognaths ( $>50$ indiv. $\mathrm{m}^{-3}$ ) from the genera Eukrohnia and Parasagitta (Fig. 3a) (289 indiv. $\mathrm{m}^{-3}$ ) was recorded at one station (KGF 51), and dense aggregations (119-530 indiv. $\mathrm{m}^{-3}$ ) of hyperiid amphipods from the genus Themisto (most likely Themisto libellula) were recorded at three locations (KGF 2S, KGF 44, KGF 9) (Table 1; Fig. 3b). It is worth noting that the amphipods occurred together with krill, while the chaetognaths were a monotypic aggregation. In addition, copepods co-occurred with krill in considerable numbers at two stations - at one station in Isfjorden (ISF 1) and one station in Hornsud (HSD 10). Due to the very small size of the copepods, it was not possible to determine their number based on the recordings from the available camera systems. Pteropods, one of the most important components of the macroplankton in the fjords of Spitsbergen (Węsławski et al. 2000; Walkusz et al. 2009), were not found at any bottom location. Krill were completely absent at 46 stations. Results grouped by location and density classes are presented in Table 1. Zooplankton aggregations were not observed in the winter season, but individual zooplankton were present at station KGF28 (1 indiv. $\mathrm{m}^{-3}$ ) and at the ISF2 and ISF3 stations (5 and 1 indiv. $\mathrm{m}^{-3}$, respectively). Nine out of eleven observations of the largest benthic aggregations of krill ( $>50$ indiv. $\mathrm{m}^{-3}$ ) were in the depth range between 60 and $100 \mathrm{~m}$, and four of them were in Atlantic type water (AW). There were no significant correlations between the formation of aggregations of zooplankton and the type and depth of the water masses (Fig. 4). 

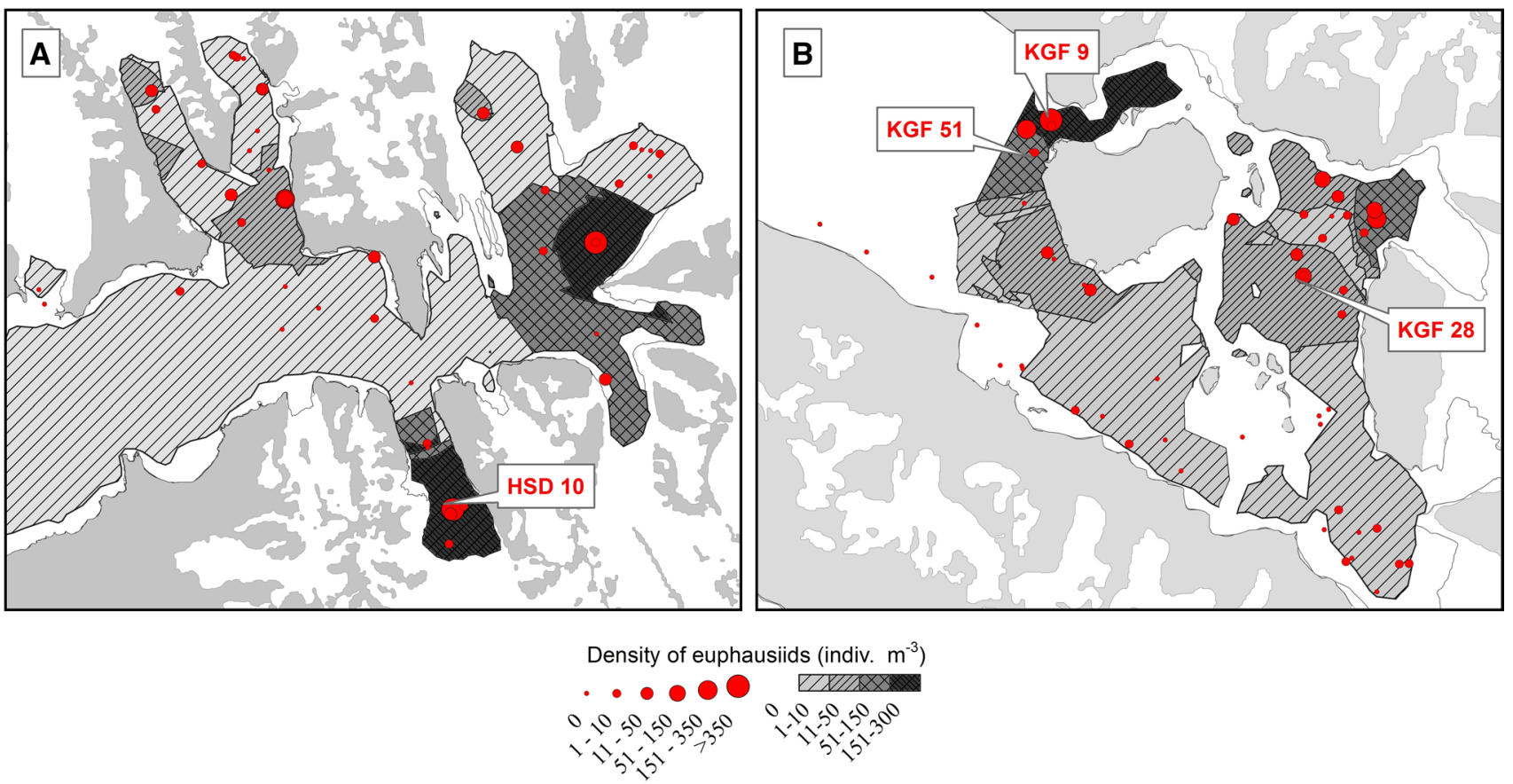

Fig. 2 Visualization of where zooplankton aggregations are most likely to form in both fjords a Hornsund, b Kongsfjorden in the summer season. The area of designated polygons is heavily dependent on the environmental factors described in the text and should be treated as indicative

\section{Assessment of the importance of benthic aggregation}

Based on the localized areas in which near-bottom krill aggregations may occur, the estimated volumes of nearbottom water layers in the present study were $0.25 \mathrm{~km}^{3}$ in Hornsund and $0.14 \mathrm{~km}^{3}$ in Kongsfjorden (Fig. 2). The biomass values (wet weight) in this volume were estimated to be 711 tons in Hornsund and 203 tons in Kongsfjorden. The krill present in the water column in Hornsund was 1130 tons (for a volume of $23.7 \mathrm{~km}^{3}$ and an average density of 0.6 indiv. $\mathrm{m}^{-3}$ ) and in Kongsfjorden there were 296 tons $\left(12.4 \mathrm{~km}^{3}\right.$ with 0.3 indiv. $\left.\mathrm{m}^{-3}\right)$. However, the percentage of the biomass in both fjords being associated with near-bottom habitats (39\% in Hornsund and $41 \%$ in Kongsfjorden) is similar in the two fjords, despite the fact that Hornsund is estimated to host twice as much krill as Kongsfjorden. Predators (such as the Atlantic cod) in Kongsfjorden were twice as numerous as predators in Hornsund (Szczucka et al. 2017), and this difference may partially explain the difference in krill biomass between these locations.

Data obtained from 52 Tucker trawl stations showed no statistically significant differences between the densities of krill in the surface and bottom layers in both fjords (Fig. 5) and between them. However, it is worth mentioning that consistently in the lower layer there were more krill individuals. The dominant species of krill in both fjords was $T$. inermis, but $T$. rashii and T. longicaudata were also registered. In Hornsund, T. inermis constituted up to $92 \%$ of total krill abundance in this fjord, T. rashii 5\% and T. longicaudata 3\%. In Kongsfjorden, T. inermis, T. rashii and T. longicaudata constituted, respectively, $78 \%, 11 \%$, and $11 \%$ but there were also recorded Meganyctiphanes norvegica (three individuals) associated with the influx of Atlantic water masses (Wesławski et al. 2017). Regarding the size of the individuals, it can be concluded that $T$. inermis population in Hornsund is mainly composed of adults (body size $>21 \mathrm{~mm}$ ), whereas in Kongsfjorden the population structure is more even (Fig. 6). There were also statistically significant differences in the numbers between upper and lower water layers for Themisto and chaetognaths in Kongsfjorden. Themisto abundance was significantly greater in Kongsfjorden. Photographic material confirmed this observations-all three Themisto aggregations were located in Kongsfjorden.

\section{Discussion}

The study of benthopelagic communities is inherently problematic (e.g. unintentional equipment contact with the sediment) and often requires modification of existing tools and the design and construction of new ones (Christiansen et al. 1999; Hirche et al. 2006, 2016). The results presented here show that traditional sampling, such as the Tucker trawl, and recently developed imaging techniques, such as the 


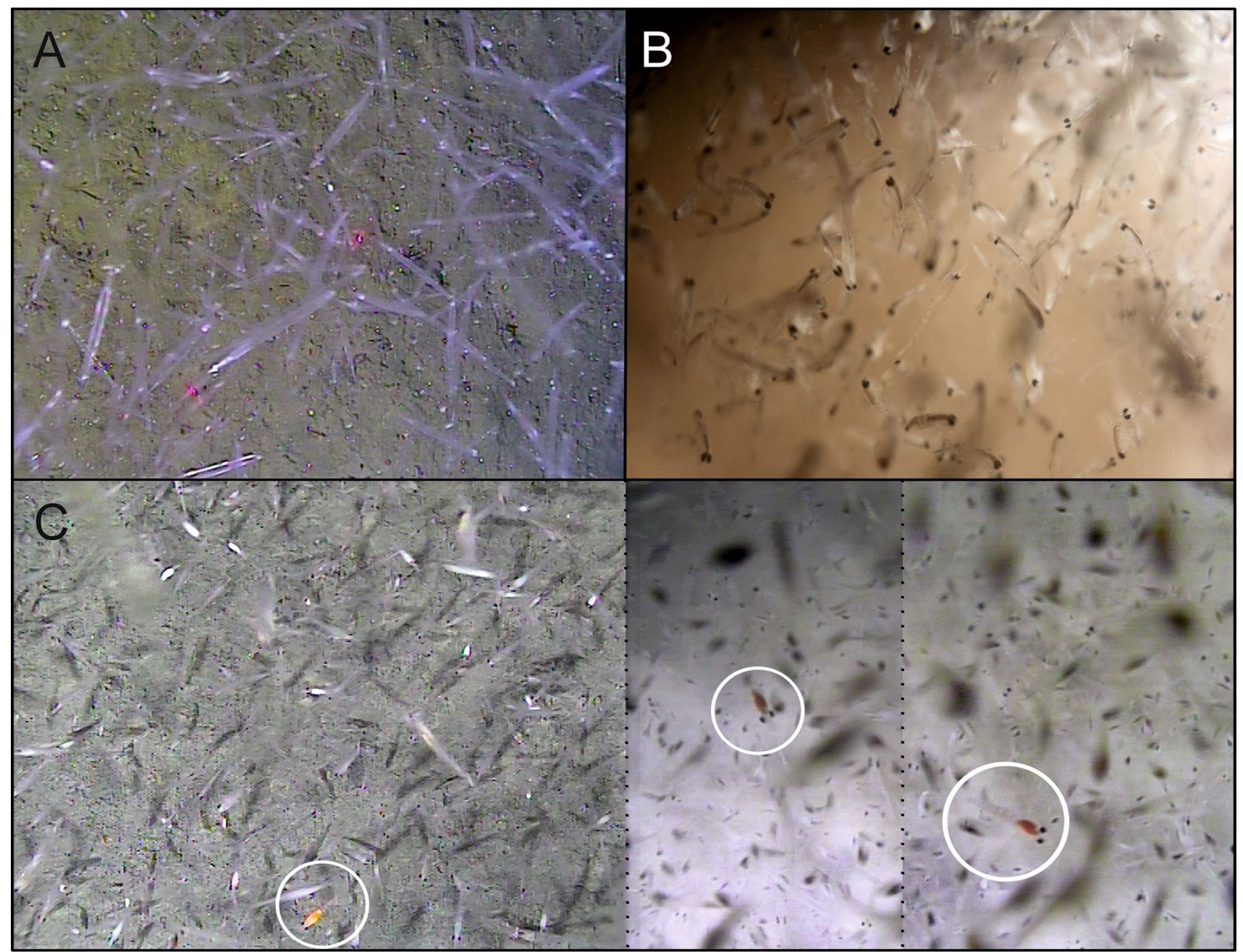

Fig. 3 a The registered aggregation of the chaetognaths, $\mathbf{b}$ hyperiid amphipods. In c, aggregations of krill with marked white circles of distinctly different individuals are shown. These individuals have a clearly orange body which may suggest the last stage of infection of the parasitoid Pseudocollinia ciliate as described by Gómez-Gutierrez et al. (2003) and Cleary et al. (2019) drop camera, photographic landers, and epibenthic sledgemounted camera, can be combined to yield a wider understanding than is possible from data obtained using any of these techniques separately.

\section{Benthic aggregations of plankton}

The drop camera allowed us to sample in places that were inaccessible to both the Tucker trawl (the area just above the bottom) and the epibenthic sledge (where sediments were too muddy). There are relatively few papers dealing with bottom benthopelagic zooplankton communities. Dense clusters of zooplankton were previously reported in the Antarctic (Euphausia superba) (Gutt and Siegel 1994; Clarke and Tyler 2008; Nicol and Brierley 2010; Fuentes et al. 2016), in the Faroe-Shetland Channel area (Hirai and Jones 2012), and in the Spitsbergen area (Laudien and Orchard 2012; Hirche et al. 2016). It is considered that the biomass of benthopelagic communities decreases exponentially with depth. At $1000 \mathrm{~m}$, the biomass is $1 \%$ that of the surface zooplankton, and at $5000 \mathrm{~m}$, this value is approximately $0.1 \%$ (Wishner 1980). However, the results presented in this paper and in the other work (Gutt and Siegel 1994) show that the average numbers of krill obtained using imaging methods are much higher than the average numbers obtained from trawls. The numbers of krill found during this study are consistent with values from the literature, e.g. $596 \pm 261$ indiv. $\mathrm{m}^{-3}$ of $\mathrm{Meg}$ anyctiphanes norvegica recorded at $480 \mathrm{~m}$ at the bottom of the Faroe-Shetland Channel (Hirai and Jones 2012). Such large numbers have the potential to impact the amount of carbon supplied to the bottom of the ocean. In most works, sinking zooplankton is treated as an artefact rather than as a significant process (Michaels et al. 1990; Wakeham et al. 1993). The importance of dead krill as a source of organic 

near the bottom; frequency of observations of the different density classes; data from 107 photo stations (see Fig. 1)
Table 1 Macrozooplankton

\begin{tabular}{|c|c|c|c|c|c|c|c|}
\hline Fjord & $\begin{array}{l}\text { Number of } \\
\text { stations }\end{array}$ & 0 & $1-10$ & $11-50$ & $51-150$ & $151-350$ & $\geq 350$ \\
\hline \multicolumn{8}{|c|}{ Abundance of Euphausiids $\mathrm{m}^{-3}$} \\
\hline Hornsund & 44 & 15 & 17 & 8 & 1 & 1 & 2 \\
\hline Isfjorden & 3 & 0 & 2 & 0 & 0 & 0 & 1 \\
\hline Kongsfjorden & 52 & 24 & 17 & 5 & 3 & 2 & 1 \\
\hline Other & 8 & 7 & 1 & 0 & 0 & 0 & 0 \\
\hline Summary & 107 & 46 & 37 & 13 & 4 & 3 & 4 \\
\hline \multicolumn{8}{|c|}{ Abundance of Chaetognaths (Eukrohnia and Parasagitta combined) $\mathrm{m}^{-3}$} \\
\hline Hornsund & 44 & 38 & 5 & 1 & 0 & 0 & 0 \\
\hline Isfjorden & 3 & 2 & 1 & 0 & 0 & 0 & 0 \\
\hline Kongsfjorden & 52 & 43 & 5 & 3 & 0 & 1 & 0 \\
\hline Other & 8 & 6 & 2 & 0 & 0 & 0 & 0 \\
\hline Summary & 107 & 89 & 13 & 4 & 0 & 1 & 0 \\
\hline \multicolumn{8}{|c|}{ Abundance of Themisto $\mathrm{m}^{-3}$} \\
\hline Hornsund & 44 & 39 & 3 & 2 & 0 & 0 & 0 \\
\hline Isfjorden & 3 & 2 & 1 & 0 & 0 & 0 & 0 \\
\hline Kongsfjorden & 52 & 37 & 7 & 5 & 0 & 2 & 1 \\
\hline Other & 8 & 8 & 0 & 0 & 0 & 0 & 0 \\
\hline Summary & 107 & 86 & 11 & 7 & 0 & 2 & 1 \\
\hline
\end{tabular}

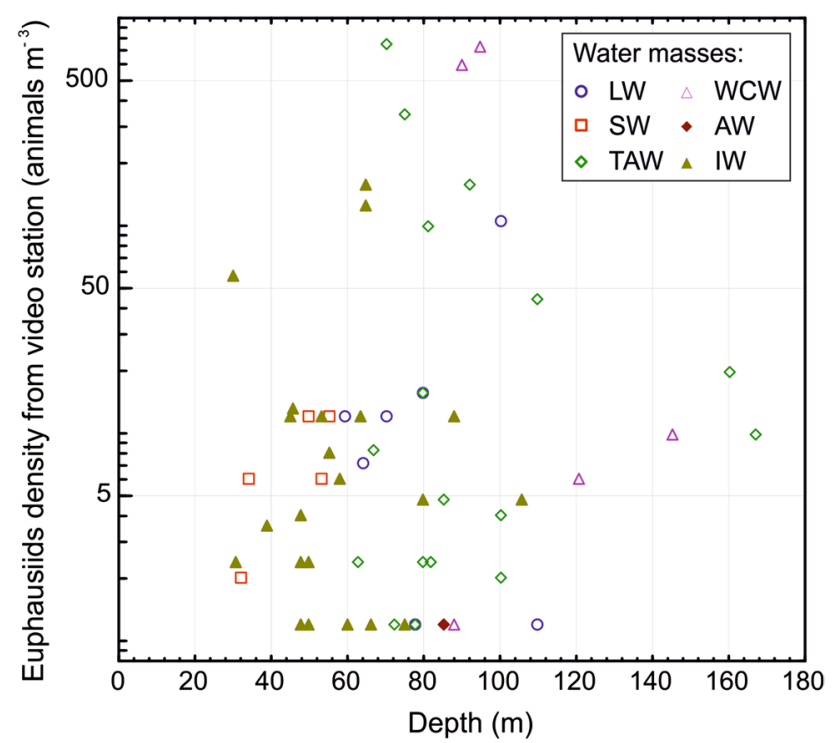

Fig. 4 Summary of all positive krill observations recorded by the drop camera with the depth and water mass type associated with each observation

matter for benthic organisms has been previously documented (Sokolova 1994).

Krill food sources include items filtered out of the water column (sponge spicules, diatoms, dinoflagellates, silicoflagellates, foraminiferans, crustacean exuviae, tintinnid ciliates), other zooplankton, and detritus from sediments (Ritz et al. 1990; Dilling et al. 1998; Nakagawa, 2004). Krill with access to the ocean bottom utilize several methods to obtain food from the sediments (Fig. 7). One method is to swim at a high angle (almost vertical) to the bottom to create a strong water current with their pleopods. This disturbs the top layer of sediment, which the animal then feeds on by filtering. In the second method, the individual swims slowly very close to the bottom and uses its antennae to plough up the surface layers of the sediment, also disturbing it and making it available for filtering. The third method is called "nose diving" (Mauchline and Fisher 1969; Clarke and Tyler 2008), where Antarctic krill (Euphausia superba) swim headfirst into the surface layer of the sediments and feed on the disturbed sediment. The nose diving method of feeding was very often observed in our research (additional video are given in Online Resource 3 ) in drop camera images from Hornsund, Kongsfjorden, and Adventfjorden (Fig. 7, Online Resource 3). The resuspension of sea floor sediment structure by krill activity was so effective that, after a short time, they had resuspended so much material that the reduced visibility prevented further observations.

It seems that the local distribution of krill (T. inermis) is more associated with close proximity to the glacier front rather than with a depth (Fig. 2). An obvious question arises as to what conditions lead to the formation of bottom aggregations.

\section{Possible scenarios}

\section{Predator avoidance strategy}

A variety of predator avoidance strategies have been described for krill and fish, the most common of which are 
Fig. 5 Whisker plots showing densities of Euphausiids, Themisto spp., and Chaetognaths from Tucker trawl samples (upper and lower water column) in both fjords. The concentration of krill was also shown with the division into species (Thysanoessa inermis, Thysanoessa longicaudata, Thysanoessa rashii). Median and range (min max) are shown

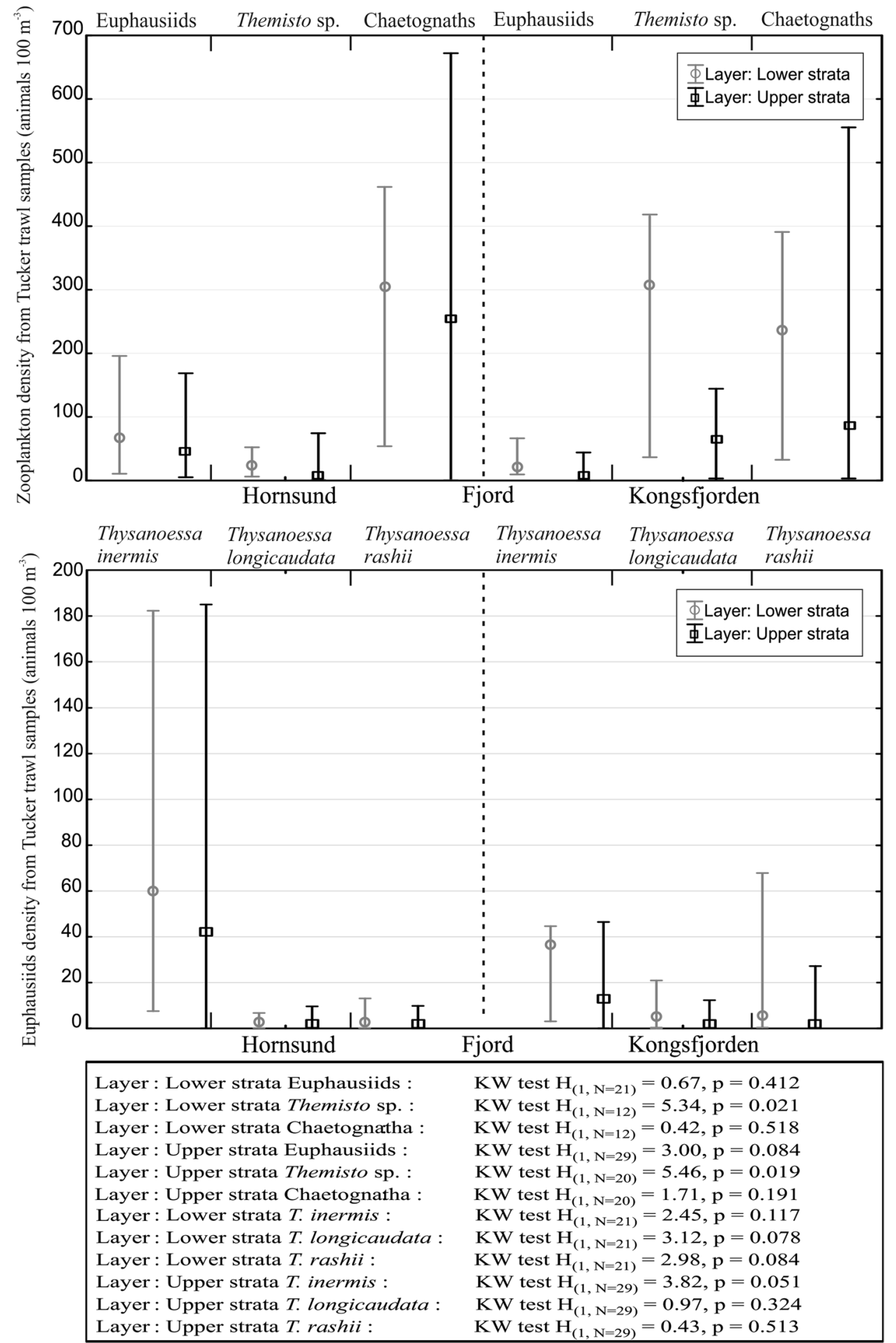

swarming and avoiding predators by escaping to the seabed (Verity and Smetacek 1996; Axelsen et al. 2001; Ryer et al. 2004; Simard and Harvey 2010). Krill in the water column may be vulnerable to predation from above, below, and all sides, while krill near the seabed are mainly vulnerable from above. Forming aggregations is another strategy that reduces mortality from predation, so forming aggregations near the bottom may be especially advantageous as it combines two strategies for avoiding predators. On the other hand, there are cases when swarms of the krill (Meganyctiphanes norvegica) were protected by large, piscivorous fish, which uses the krill swarms as a feeding ground in their hunt for planktivores (Kaartvedt et al. 2005). It should be also taken into account that krill interaction with sea floor may actually 

tion of Euphausiids length in Tucker Trawl samples collected for both fjords. Mean and range (min max) are shown
Fig. 6 Density and distribuin 2016. Data shown separately

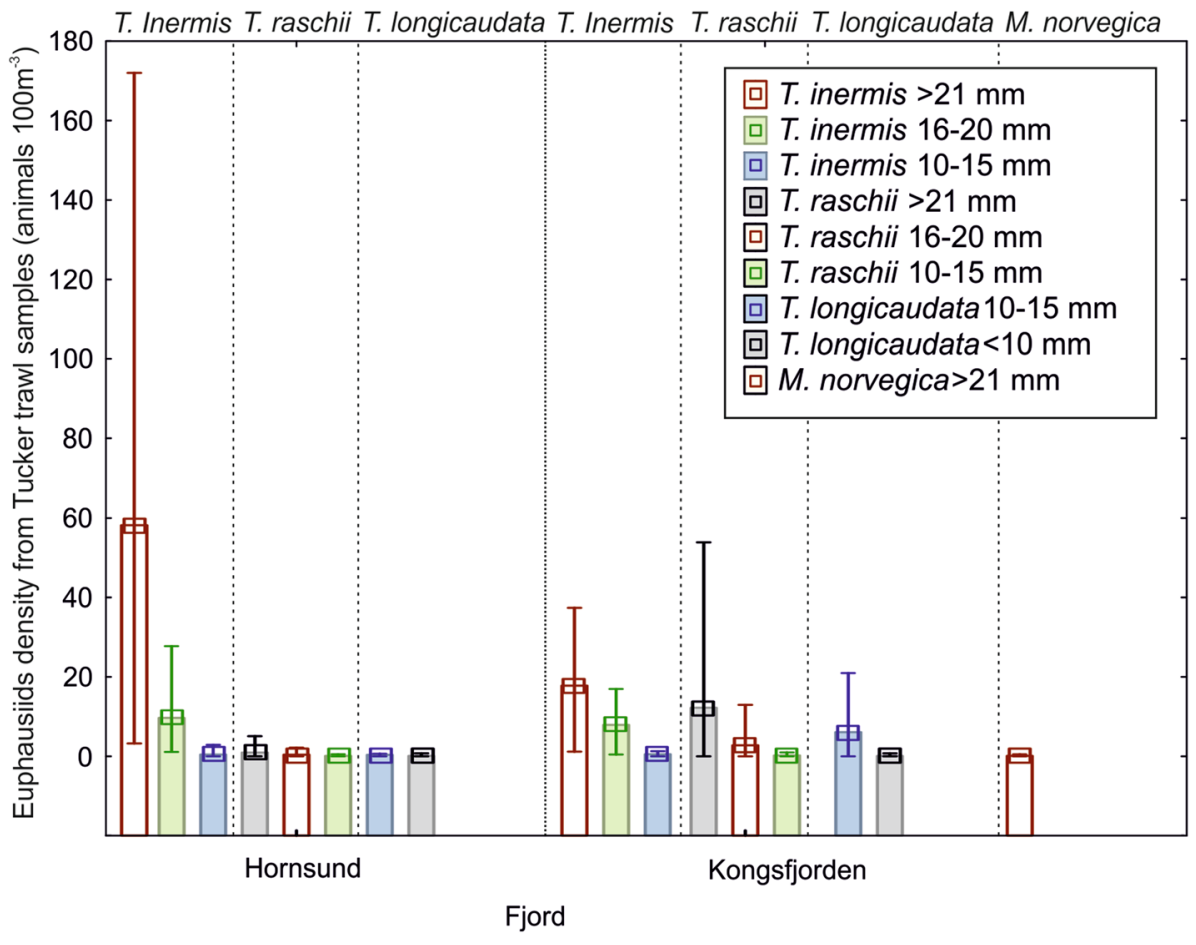

expose to different predators like demersal fishes and sea anemones.

The density of cod feeding on krill is much higher in Kongsfjorden than in Hornsund (Szczucka et al. 2017), which may explain why a larger part of the krill population occurs near the seabed in Kongsfjorden than in Hornsund (which has low numbers of predatory fish). Acoustic data showing the distribution and size of fish in the water column for both of the fjords discussed here (Szczucka et al. 2017) support this idea. The lowest density of fish occurs in the glacial bays is consistent with the maximum occurrences of krill (Brepolen, Samarinvagen in Hornsund and near the glacier front of Blomstrandbreen, Convaybreen in Kongsfjorden) (Fig. 2). Glacial bays are characterized by specific environmental factors, including a large amount of mineral suspension in the water column and a strong gradient between brackish waters at the surface and higher salinity waters at depth. Large predators, such as Atlantic cod, tend to avoid glacial bays (Szczucka et al. 2017).

\section{Sedimentation and glacier trap}

Estuarine circulation in the glaciated fjords is driven by catabatic winds (Węsławski et al. 2000; Lydersen et al. 2014). This process starts in June when ablation intensifies and ends in September when the air temperature drops, leading to a significant decrease in the inflow of suspended sediments and the volume of fresh water (Węsławski et al. 1995). There are also known cases of mass mortality of krill (Węsławski and Legżyńska 1998), phytoplankton (Hernando et al. 2015), and amphipods (Eiane and Daase 2002) as a result of osmotic shock resulting from the direct proximity of the glacier or the glacial river. On the other hand, previous research demonstrates the high tolerance of the krill Euphausia superba to a wide salinity range from 25 to 45 (Aareset and Torres 1989). It is believed that a large amount of suspended material in glacial bays has a negative effect on the functioning of coastal ecosystems (Thrush et al. 2003). High concentrations of suspended material in the water column can adversely affect krill by clogging the filtration apparatus used for feeding. When sediment concentrations are high, krill may ingest predominantly inorganic mineral particles. Additionally, mineral particles of glacial origin $\left(>1.1 \times 10^{5} \mu \mathrm{m}^{3}\right)$ with sharp edges can mechanically destroy the krill (Fuentes et al. 2016). Dead zooplankton can be periodically stranded, creating swaths of dead organisms on the shore. This has been recorded in the southern (Fuentes et al. 2016) and northern polar regions (Legeżyńska et al. 2000; Eiane and Daase 2002). Dead krill have also been recorded in large numbers during dredging in an Antarctic fjord, in the form of large aggregations on the seabed (Sicinski personal communication, Balazy unpublished photography). A dense concentration of suspended material in the tidewater glacier area is likely to be a cause of high krill mortality (Lewis and Syvitski 1983; Węsławski and Legeżyńska 1998). Suspended plumes on the surface, which come directly from the outflows of glaciers or glacial rivers, are a common occurrence (Zajaczkowski 2008). Numerous mineral particles from the flocculation process combine in the deeper parts of the water column into large flocs that can build up on the boundary of various water masses thus 


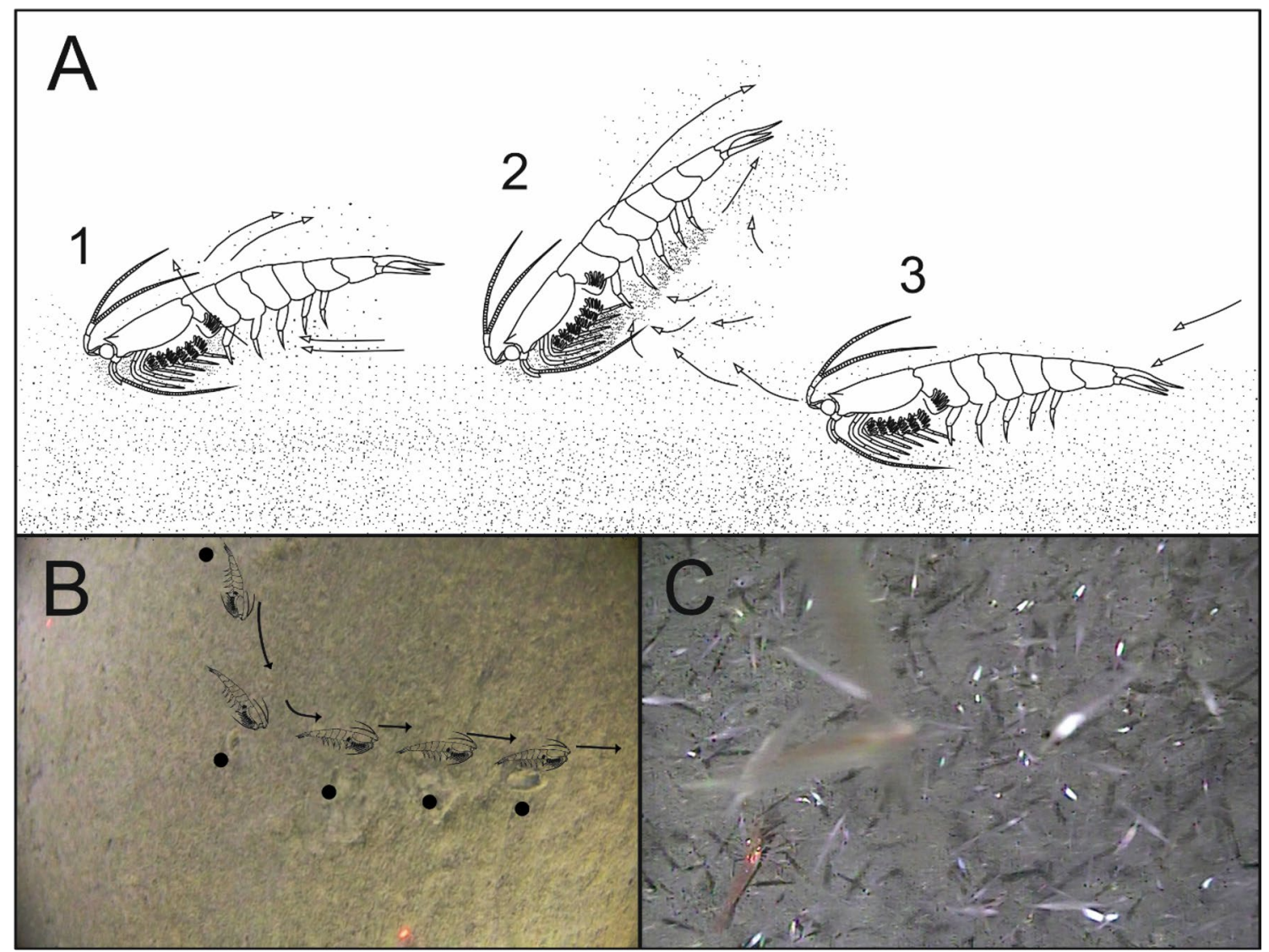

Fig. 7 Three methods of krill feeding at the sea bottom. Methods 1 and 3 may be convergent, and differences in the depth of the individual result from the degree of hydration of the upper layer of the sediment (fluffy, nepheloid layer), edited from Mauchline and Fisher (1969). Behaviour number 3 was first observed by Clarke and Tyler (2008), calling them nose diving. In most observations, feeding activity was calm when there were few krill present and the individuals

creating a reservoir of cleaner water that may trap the planktonic organisms below. The estuarine circulation, driven by a rapid influx of glacial meltwater, may be responsible for zooplankton retention in the inner parts of the fjord (Węsławski et al. 2000). There, the high sediment load and surface salinity gradient result in high zooplankton mortality. Stunned and dead krill are forced to the surface by glacial outflow, where they are an excellent source of food for seabirds (Urbanski et al. 2017). These conditions also create a perfect feeding site for necrophagous crustaceans. Large concentrations of birds in the study area, mainly Black-legged kittiwakes (Rissa tridactyla), were recorded in 2015 for both fjords (Urbański et al. 2017) and correlate with the large numbers of krill in the near-bottom aggregations at this time. Analysis of the photos showed large densities of echinoderms and anemones from the genus Cerianthus near the glacier, which may also be feeding on dead krill. The population of ophiuroids in the Spitsbergen fjords had very high concentrations near the glacier fronts (Deja el al. 2016), which may be associated delved into the sediment at regular intervals (b); additional data are given in Online Resource 1 "ESM_1.mp4". Black dots symbolize the places where the nose diving activity of one individual occurred. When krill were more abundant, feeding behaviour was more chaotic, nervous (c). A number of krill feeding simultaneously have the potential to resuspended a lot of sediment

with bottom macrozooplankton aggregations. In Antarctica, dead euphausiids were the main source of food for abyssal ophiuroids (Sokolova 1994).

\section{Parasitoid apostome ciliates}

One of the few well-explained causes of mass mortalities is parasitoid apostome ciliates (Gómez-Gutiérrez et al. 2003, 2017). Thysanoessa inermis and Thysanoessa raschii are infected with parasitoid ciliates of the genus Pseudocollinia that kill krill in < 3 days (Capriulo and Small 1986; Capriulo et al. 1991; Lynn et al. 2014) Krill individuals infected with Pseudocollinia can be easily visually recognized. Their body loses transparency and changes colour from beige to orange depending on the stage of infection and characteristically swells the cephalothorax (Gómez-Gutiérrez et al. 2003, Gómez-Gutiérrez and Robinson 2006; Lynn et al. 2014). In our studies, distinctive, clearly orange individuals were observed on several dozen video stations and maybe they are 
infected (Fig. 3c). Not many such changed individuals were observed; however, there were not registered dead individuals at the bottom, which usually accompanies such infections (Gómez-Gutiérrez et al. 2003).

\section{Possible errors in the methodology}

The numbers of krill presented in this work should be interpreted with some caution. Collecting camera images below the euphotic zone necessitates the use of artificial lighting. This method may introduce error that results in overestimating the densities of the individuals. Positive phototaxis of zooplankton in Kongsfjorden in response to ROV lighting has been previously shown (Hirche et al. 2016). Another study also noted the influence of artificial lighting on animal concentrations (Gutt and Siegel 1994). Strategies employed to minimize this error included continuous horizontal drop camera movement over the bottom $(0.05-0.1 \mathrm{~m} / \mathrm{s})$, absence of propulsors (which can deter zooplankton), and the method of selecting the still photos from the beginning, middle, and end of the recording period. At most of the surveyed stations where large numbers of krill were observed, they appeared immediately after seabed became visible; consequently, the effect of density increasing with the length of the transect was noticeable but small. The coefficient of variation (defined as the ratio of standard deviation to average and expressed in percentage) does not exceed $30 \%$.

\section{Conclusion}

This study point out that not using methods allowing to sample also in the bottom layer of water leads to a huge underestimation of the zooplankton biomass in Spitsbergen fjords.
It was estimated that bottom aggregations of krill make up over $39 \%$ of the total krill biomass in Hornsund and $41 \%$ in Kongsfjorden. Our observations also show that dominated in Spitsbergen euphasiid species-T. inermis creates bottom aggregation mainly in close vicinity to glacier front. Recorded behaviour known as "nose diving" suggests that near-bottom habitat is chosen by krill due to the availability of food in this region.

Acknowledgements We are grateful to Michał Procajło for help with laboratory work and with Tucker trawl data, and we thank Jorgen Berge for allowing participation in the Helmer Hansen polar-night UNIS cruise in 2014. Jan Marcin Weslawski is acknowledged for support in the field and discussions on the results. Fieldwork was supported by the GAME NCN Maestro project and by the Polish-Norwegian Research Programme operated by the National Centre for Research and Development under the Norwegian Financial Mechanism 2009-2014 in the frame of Project Contract No POL-NOR/199377/91/2014 (GLAERE) and the Leading National Research Centre (KNOW) received by the Centre for Polar Studies from 2014 to 2018.

\section{Compliance with ethical standards}

Conflict of interest The authors declare that there is no conflict of interest in presenting this information.

Open Access This article is distributed under the terms of the Creative Commons Attribution 4.0 International License (http://creativeco mmons.org/licenses/by/4.0/), which permits unrestricted use, distribution, and reproduction in any medium, provided you give appropriate credit to the original author(s) and the source, provide a link to the Creative Commons license, and indicate if changes were made.
Table 2 Station name, date, depth, location, krill densities, and type of gear from photo stations used in this study (summer season 2013, 2014, 2015, 2016, 2017, and winter 2016); krill densities in indiv. $\mathrm{m}^{-3}$

\begin{tabular}{lllllll}
\hline Station & Date & Depth $(\mathrm{m})$ & Latitude & Longitude & $\begin{array}{l}\text { Euphausiacea } \\
\text { abundance } \mathrm{m}^{-3}\end{array}$ & Gear type \\
\hline HSD1 & 27.07 .2015 & 65 & 77.041 & 16.027 & 124 & Drop camera \\
HSD1 & 28.07 .2015 & 65 & 77.041 & 16.027 & 156 & Drop camera \\
HSD10 & 30.07 .2015 & 95 & 76.926 & 16.290 & 731 & Drop camera \\
HSD11 & 30.07 .2015 & 121 & 77.023 & 16.533 & 6 & Drop camera \\
HSD12 & 30.07 .2015 & 70 & 76.989 & 16.531 & 0 & Drop camera \\
HSD13 & 30.07 .2015 & 70 & 76.973 & 16.544 & 12 & Drop camera \\
HSD14 & 30.07 .2015 & 50 & 77.019 & 16.171 & 12 & Drop camera \\
HSD15 & 29.07 .2016 & 50 & 77.058 & 16.599 & 2 & Drop camera \\
HSD16 & 29.07 .2016 & 56 & 77.056 & 16.613 & 0 & Drop camera \\
HSD17 & 29.07 .2016 & 62 & 77.056 & 16.627 & 0 & Drop camera \\
HSD18 & 29.07 .2016 & 66 & 77.054 & 16.642 & 1 & Drop camera \\
HSD19 & 29.07 .2016 & 60 & 77.044 & 16.574 & 1 & Drop camera \\
HSD1S & 01.08 .2016 & 106 & 77.008 & 15.853 & 5 & Epibenthic sledge \\
HSD2 & 28.07 .2015 & 70 & 77.093 & 15.963 & 0 & Drop camera \\
HSD20 & 01.08 .2016 & 31 & 76.914 & 16.283 & 2 & Drop camera \\
\hline
\end{tabular}


Table 2 (continued)

\begin{tabular}{|c|c|c|c|c|c|c|}
\hline Station & Date & Depth (m) & Latitude & Longitude & $\begin{array}{l}\text { Euphausiacea } \\
\text { abundance } \mathrm{m}^{-3}\end{array}$ & Gear type \\
\hline HSD21 & 01.08 .2016 & 80 & 76.925 & 16.286 & 16 & Drop camera \\
\hline HSD22 & 31.07 .2016 & 84 & 76.973 & 16.227 & 0 & Drop camera \\
\hline HSD23 & 31.07 .2016 & 78 & 77.094 & 15.946 & 1 & Drop camera \\
\hline HSD24 & 31.07 .2016 & 84 & 77.066 & 15.984 & 0 & Drop camera \\
\hline HSD25 & 30.07 .2014 & 160 & 77.082 & 15.811 & 20 & Drop camera \\
\hline HSD26 & 30.07 .2014 & 167 & 77.075 & 15.818 & 10 & Drop camera \\
\hline HSD27 & 29.07 .2014 & 55 & 77.046 & 16.625 & 0 & Drop camera \\
\hline HSD28 & 30.07 .2013 & 84 & 77.001 & 16.079 & 0 & Lander \\
\hline HSD29 & 30.07 .2013 & 107 & 77.009 & 16.025 & 0 & Lander \\
\hline HSD2S & 01.08 .2016 & 78 & 77.059 & 15.970 & 0 & Epibenthic sledge \\
\hline HSD3 & 28.07 .2015 & 55 & 77.082 & 15.993 & 12 & Drop camera \\
\hline HSD30 & 30.07 .2013 & 105 & 76.993 & 16.018 & 0 & Lander \\
\hline HSD31 & 31.07 .2017 & 63.5 & 77.043 & 15.939 & 12 & Drop camera \\
\hline HSD32 & 31.07 .2017 & 46 & 77.071 & 16.355 & 13 & Drop camera \\
\hline HSD33 & 31.07 .2017 & 59 & 77.058 & 16.409 & 12 & Drop camera \\
\hline HSD34 & 31.07 .2017 & 88 & 77.020 & 16.447 & 1 & Drop camera \\
\hline HSD35 & 31.07 .2017 & 145 & 76.927 & 16.308 & 10 & Drop camera \\
\hline HSD36 & 31.07 .2017 & 118 & 76.949 & 16.251 & 0 & Drop camera \\
\hline HSD37 & 31.07 .2017 & 30 & 77.052 & 16.002 & 0 & Drop camera \\
\hline HSD38 & 31.07 .2017 & 64 & 77.042 & 16.453 & 7 & Drop camera \\
\hline HSD39 & 31.07 .2017 & 80 & 77.081 & 15.991 & 5 & Drop camera \\
\hline HSD4 & 28.07 .2015 & 32 & 77.055 & 15.891 & 2 & Drop camera \\
\hline HSD40 & 31.07 .2017 & 75 & 77.093 & 15.952 & 1 & Drop camera \\
\hline HSD41 & 31.07 .2017 & 110 & 76.951 & 16.251 & 1 & Drop camera \\
\hline HSD5 & 28.07.2015 & 34 & 77.033 & 15.955 & 6 & Drop camera \\
\hline HSD6 & 28.07 .2015 & 53 & 76.997 & 16.169 & 6 & Drop camera \\
\hline HSD7 & 28.07 .2015 & 90 & 77.023 & 16.533 & 587 & Drop camera \\
\hline HSD8 & 29.07 .2015 & 22 & 77.004 & 15.631 & 0 & Drop camera \\
\hline HSD9 & 29.07 .2015 & 54 & 77.009 & 15.623 & 0 & Drop camera \\
\hline ISF1 & 02.08 .2015 & 40 & 78.241 & 15.641 & 426 & Drop camera \\
\hline ISF2 & 11.01.2016 & 56 & 78.649 & 16.875 & 5 & Drop camera \\
\hline ISF3 & 01.01 .2016 & 64 & 78.258 & 13.795 & 1 & Drop camera \\
\hline KGF1 & 03.08 .2015 & 25 & 78.933 & 11.923 & 0 & Drop camera \\
\hline KGF11 & 06.08 .2015 & 100 & 78.968 & 11.658 & 0 & Drop camera \\
\hline KGF12 & 06.08 .2015 & 100 & 78.961 & 11.726 & 0 & Drop camera \\
\hline KGF13 & 06.08 .2015 & 100 & 78.956 & 11.820 & 0 & Drop camera \\
\hline KGF14 & 06.08 .2015 & 100 & 78.943 & 11.888 & 0 & Drop camera \\
\hline KGF15 & 06.08 .2015 & 100 & 78.932 & 11.955 & 0 & Drop camera \\
\hline KGF16 & 06.08 .2015 & 100 & 78.922 & 12.032 & 4 & Drop camera \\
\hline KGF17 & 06.08 .2015 & 100 & 78.913 & 12.110 & 2 & Drop camera \\
\hline KGF18 & 06.08 .2015 & 100 & 78.907 & 12.185 & 0 & Drop camera \\
\hline KGF19 & 07.08 .2015 & 74 & 78.877 & 12.468 & 0 & Drop camera \\
\hline KGF1S & 04.08 .2016 & 280 & 78.977 & 11.945 & 0 & Epibenthic sledge \\
\hline KGF2 & 05.08 .2015 & 100 & 78.980 & 12.441 & 105 & Drop camera \\
\hline KGF20 & 07.08 .2015 & 93 & 78.885 & 12.430 & 0 & Drop camera \\
\hline KGF21 & 07.08 .2015 & 88 & 78.954 & 12.045 & 12 & Drop camera \\
\hline KGF22 & 07.08 .2015 & 110 & 78.964 & 11.982 & 44 & Drop camera \\
\hline KGF23 & 07.08 .2015 & 100 & 78.991 & 11.951 & 0 & Drop camera \\
\hline KGF24 & 20.01 .2016 & 93 & 78.933 & 11.954 & 0 & Drop camera \\
\hline KGF25 & 21.01.2016 & 105 & 78.917 & 12.269 & 0 & Drop camera \\
\hline
\end{tabular}


Table 2 (continued)

\begin{tabular}{|c|c|c|c|c|c|c|}
\hline Station & Date & Depth (m) & Latitude & Longitude & $\begin{array}{l}\text { Euphausiacea } \\
\text { abundance } \mathrm{m}^{-3}\end{array}$ & Gear type \\
\hline KGF26 & 23.01 .2016 & 44 & 78.925 & 12.389 & 0 & Drop camera \\
\hline KGF27 & 23.01 .2016 & 44 & 78.921 & 12.378 & 0 & Drop camera \\
\hline KGF28 & 23.01 .2016 & 72 & 78.961 & 12.345 & 1 & Drop camera \\
\hline KGF29 & 07.08.2016 & 67 & 78.998 & 11.978 & 8 & Drop camera \\
\hline KGF2S & 05.08 .2016 & 90 & 78.893 & 12.439 & 0 & Epibenthic sledge \\
\hline KGF3 & 05.08 .2015 & 48 & 78.978 & 12.403 & 4 & Drop camera \\
\hline KGF30 & 05.08 .2016 & 80 & 78.967 & 12.334 & 16 & Drop camera \\
\hline KGF31 & 07.08 .2016 & 82 & 78.894 & 12.464 & 2 & Drop camera \\
\hline KGF32 & 06.08 .2016 & 85 & 79.070 & 11.610 & 1 & Drop camera \\
\hline KGF33 & 08.08 .2016 & 58 & 78.958 & 12.402 & 6 & Drop camera \\
\hline KGF34 & 07.08 .2016 & 92 & 78.977 & 12.445 & 157 & Drop camera \\
\hline KGF35 & 08.08 .2016 & 39 & 78.951 & 12.401 & 4 & Drop camera \\
\hline KGF36 & 07.08 .2016 & 78 & 78.898 & 12.409 & 1 & Drop camera \\
\hline KGF37 & 08.08 .2016 & 63 & 78.973 & 12.428 & 2 & Drop camera \\
\hline KGF38 & 07.08 .2016 & 64 & 78.893 & 12.390 & 0 & Drop camera \\
\hline KGF39 & 07.08 .2016 & 47.5 & 78.885 & 12.511 & 1 & Drop camera \\
\hline KGF4 & 05.08 .2015 & 42 & 78.977 & 12.381 & 0 & Drop camera \\
\hline KGF40 & 07.08 .2016 & 48 & 78.884 & 12.498 & 2 & Drop camera \\
\hline KGF41 & 07.08 .2013 & 90 & 78.931 & 12.145 & 0 & Lander \\
\hline KGF42 & 08.08 .2013 & 115 & 78.921 & 12.071 & 0 & Lander \\
\hline KGF43 & 08.08 .2013 & 98 & 78.915 & 12.161 & 0 & Lander \\
\hline KGF44 & 10.08 .2013 & 75 & 78.997 & 11.943 & 340 & Lander \\
\hline KGF45 & 08.08.2017 & 50 & 78.971 & 12.369 & 1 & Drop camera \\
\hline KGF46 & 08.08 .2017 & 81 & 78.961 & 12.345 & 100 & Drop camera \\
\hline KGF47 & 08.08 .2017 & 43 & 78.924 & 12.376 & 0 & Drop camera \\
\hline KGF48 & 08.08 .2017 & 85 & 78.885 & 12.423 & 5 & Drop camera \\
\hline KGF49 & 07.08 .2017 & 70 & 78.956 & 12.036 & 0 & Drop camera \\
\hline KGF5 & 05.08 .2015 & 53 & 78.983 & 12.389 & 12 & Drop camera \\
\hline KGF50 & 07.08 .2017 & 62 & 78.962 & 11.991 & 0 & Drop camera \\
\hline KGF51 & 07.08 .2017 & 80 & 78.991 & 11.957 & 2 & Drop camera \\
\hline KGF6 & 05.08 .2015 & 30 & 78.987 & 12.365 & 58 & Drop camera \\
\hline KGF7 & 05.08 .2015 & 55 & 78.978 & 12.341 & 8 & Drop camera \\
\hline KGF8 & 05.08 .2015 & 45 & 78.975 & 12.242 & 12 & Drop camera \\
\hline KGF9.10 & 06.08 .2015 & 70 & 79.000 & 11.977 & 751 & Drop camera \\
\hline MG1 & 01.01 .2016 & 98 & 79.556 & 11.128 & 0 & Drop camera \\
\hline RAU1 & 10.08 .2017 & 52 & 79.702 & 12.232 & 0 & Drop camera \\
\hline RAU2 & 10.08 .2017 & 67 & 79.738 & 12.470 & 2 & Drop camera \\
\hline RIP1 & 14.01.2016 & 84 & 80.300 & 22.345 & 0 & Drop camera \\
\hline SH1 & 03.08 .2015 & 50 & 78.206 & 11.645 & 0 & Drop camera \\
\hline $\mathrm{SH} 2$ & 03.08 .2015 & 50 & 78.945 & 10.274 & 0 & Drop camera \\
\hline SH3 & 03.08 .2015 & 50 & 79.082 & 10.689 & 0 & Drop camera \\
\hline SM1 & 13.01.2016 & 81 & 79.790 & 11.024 & 0 & Drop camera \\
\hline
\end{tabular}

During the summer season, there was always daylight; during winter there were only darkness 
Table 3 Station name, date, depth, location, and krill densities from Tucker trawl samples used in this study (summer 2014, 2015, and 2016); krill densities in indiv. $100 \mathrm{~m}^{-3}$

\begin{tabular}{|c|c|c|c|c|c|c|}
\hline$\overline{\text { Station }}$ & Date & Depth (m) & Latitude (N) & Longitude (E) & $\begin{array}{l}\text { Krill } 100 \mathrm{~m}^{-3} \text { upper } \\
\text { strata }\end{array}$ & $\begin{array}{l}\text { Krill } 100 \mathrm{~m}^{-3} \\
\text { lower strata }\end{array}$ \\
\hline 14003/GL & 7.2014 & 25 & 77.046 & 16.628 & 62.1 & - \\
\hline 14004/GL & 7.2014 & 25 & 77.040 & 16.598 & 5.2 & - \\
\hline 14010/GL & 7.2014 & 25 & 77.073 & 15.846 & 11.6 & - \\
\hline 14011/GL & 7.2014 & 25 & 77.056 & 15.856 & 21.2 & - \\
\hline 14016/GL & 8.2014 & 25 & 78.979 & 12.417 & 40.9 & - \\
\hline 14017/GL & 8.2014 & $30-25$ & 78.980 & 12.417 & 0.2 & - \\
\hline 14,024/GL & 8.2014 & 30 & 78.896 & 12.434 & 1.7 & - \\
\hline 14025/GL & 8.2014 & 30 & 78.884 & 12.445 & 43.1 & - \\
\hline $\mathrm{H} 2$ & 30.07 .2015 & $150-200$ & 76.983 & 15.759 & - & 10.7 \\
\hline $\mathrm{H} 2$ & 30.07 .2015 & $15-20$ & 76.983 & 15.759 & 8.7 & - \\
\hline HGLA1 & 29.07.2016 & 68 & 77.053 & 16.652 & - & 63.3 \\
\hline HGLA1 & 29.07 .2016 & 15 & 77.054 & 16.653 & 185.3 & - \\
\hline HGLA3 & 29.07 .2016 & 55 & 77.039 & 16.599 & - & 93.4 \\
\hline HGLA3 & 29.07 .2016 & 15 & 77.044 & 16.567 & 192.8 & - \\
\hline HGLA4 & 31.07 .2016 & 85 & 77.094 & 15.941 & - & 14.1 \\
\hline HGLA4 & 31.07 .2016 & 15 & 77.090 & 15.949 & 38.9 & - \\
\hline HGLA5 & 31.07 .2016 & 86 & 77.067 & 15.978 & - & 13.4 \\
\hline HGLA5 & 31.07 .2016 & 15 & 77.089 & 15.934 & 20.3 & - \\
\hline HGLA6 & 01.08 .2016 & $15-40$ & 76.913 & 16.301 & 10.8 & - \\
\hline HGLA6 & 01.08 .2016 & 30 & 76.925 & 16.284 & 0 & - \\
\hline KB3 & 07.08 .2015 & $250-290$ & 78.941 & 76.516 & - & 66.6 \\
\hline KB3 & 07.08.2015 & $10-25$ & 78.941 & 76.516 & 7.9 & - \\
\hline KB4 & 07.08.2015 & $50-60$ & 78.903 & 12.230 & - & 22.2 \\
\hline KB4 & 07.08 .2015 & $10-25$ & 78.903 & 12.230 & 0 & 0 \\
\hline KB5 & 07.08 .2015 & $15-25$ & 78.885 & 12.430 & 44.2 & - \\
\hline KB5 & 07.08 .2015 & $45-75$ & 78.885 & 12.430 & - & 9.7 \\
\hline KB5 SILL & 07.08 .2015 & $10-25$ & 78.898 & 12.318 & 1.7 & - \\
\hline KGLA1 & 07.08.2016 & 50 & 78.885 & 12.505 & - & 64.9 \\
\hline KGLA1 & 07.08.2016 & 15 & 78.884 & 12.497 & 15.1 & - \\
\hline KGLA2 & 07.08 .2016 & $42-74$ & 78.893 & 12.384 & - & 51.9 \\
\hline KGLA2 & 07.08.2016 & 15 & 78.892 & 12.403 & 53 & - \\
\hline KGLA3 & 08.08.2016 & $40-48$ & 78.976 & 12.441 & - & 8.9 \\
\hline KGLA3 & 08.08.2016 & 15 & 78.984 & 12.396 & 2.2 & - \\
\hline KGLA4 & 08.08 .2016 & 15 & 78.973 & 12.423 & 59 & - \\
\hline KGLA4 & 08.08 .2016 & 53 & 78.956 & 12.423 & - & 127.2 \\
\hline MB1 & 29.07.2015 & 80-100 & 77.092 & 15.962 & - & 14.7 \\
\hline MB1 & 29.07.2015 & $5-15$ & 77.092 & 15.962 & 168.7 & - \\
\hline MB2 & 29.07.2015 & $50-70$ & 77.092 & 15.962 & - & 68 \\
\hline MB2 & 29.07.2015 & $5-15$ & 77.092 & 15.962 & 103.5 & - \\
\hline MEN1 & 30.07 .2015 & $50-70$ & 77.022 & 16.533 & - & 57.8 \\
\hline MEN1 & 30.07 .2015 & $5-15$ & 77.022 & 16.533 & 9.6 & - \\
\hline MEN2 & 30.07 .2015 & $30-40$ & 76.989 & 16.530 & - & 165.6 \\
\hline MEN2 & 30.07 .2015 & $5-15$ & 76.989 & 16.530 & 50.3 & - \\
\hline P1 & 29.07.2015 & 80-100 & 77.066 & 15.851 & - & 77 \\
\hline P1 & 29.07.2015 & $5-15$ & 77.066 & 15.851 & 89.3 & - \\
\hline $\mathrm{P} 2$ & 29.07.2015 & 80-100 & 77.061 & 15.865 & - & 196 \\
\hline $\mathrm{P} 2$ & 29.07.2015 & $5-15$ & 77.061 & 15.865 & 93.4 & - \\
\hline S1 & 30.07 .2015 & $50-40$ & 76.926 & 16.290 & - & 120.6 \\
\hline
\end{tabular}


Table 3 (continued)

\begin{tabular}{lllllll}
\hline Station & Date & Depth $(\mathrm{m})$ & Latitude $(\mathrm{N})$ & Longitude (E) & $\begin{array}{l}\text { Krill } 100 \mathrm{~m}^{-3} \text { upper } \\
\text { strata }\end{array}$ & $\begin{array}{l}\text { Krill } 100 \mathrm{~m}^{-3} \\
\text { lower strata }\end{array}$ \\
\hline S1 & 30.07 .2015 & $5-15$ & 76.926 & 16.290 & 13.3 & - \\
S2 & 30.07 .2015 & $80-100$ & 76.939 & 16.268 & - & 57.9 \\
S2 & 30.07 .2015 & $5-15$ & 76.939 & 16.268 & 45.1 & - \\
\hline
\end{tabular}

\section{References}

Aarset AV, Torres JJ (1989) Cold resistance and metabolic responses to salinity variations in the amphipod Eusirus antarcticus and the krill Euphausia superba. Polar Biol. https://doi.org/10.1007/ BF00261032

Axelsen BE, Anker-Nilssen T, Fossum P, Kvamme C, Nøttestad L (2001) Pretty patterns but a simple strategy: predator-prey interactions between juvenile herring and Atlantic puffins observed with multibeam sonar. Can J Zool. https://doi.org/10.1139/ cjz-79-9-1586

Brierley AS (2008) Antarctic ecosystem: are deep drill ecological outliers or portents of a paradigm shift? Curr Biol. https://doi. org/10.1016/j.cub.2008.01.022

Buchholz F, Buchholz C (2010) Growth and moulting in northern krill (Meganyctiphanes norvegica Sars). In: Tarling GA (ed) Advances in marine biology-biology of northern krill. Academic Press, Amsterdam, pp 173-197

Capriulo GM, Small EB (1986) Discovery of an apostome ciliate (Collinia beringensis n.sp.) endoparasitic in the Bering Sea euphausiid Thysanoessa inermis. Dis Aquat Org 1:141-146

Capriulo GM, Pedone MJ, Small EB (1991) High apostome ciliate endoparasite infection rates found in the Bering Sea euphausiid Thysanoessa inermis. Mar Ecol Prog Ser 72:203-204

Christiansen B, Drueke B, Koppelmann R, Weikert H (1999) The near-bottom zooplankton at the abyssal BIOTRANS site, northeast Atlantic: composition, abundance and variability. J Plankton Res. https://doi.org/10.1093/plankt/21.10.1847

Clarke A, Tyler PA (2008) Adult Antarctic krill feeding at abyssal depths. Curr Biol. https://doi.org/10.1016/j.cub.2008.01.059

Cleary AC, Durbin EG, Rynearson TA (2012) Krill feeding on sediment in the Gulf of Maine (North Atlantic). Mar Ecol Prog Ser. https://doi.org/10.3354/meps09632

Cleary AC, Casas MC, Durbin EG, Gómez-Gutiérrez J (2019) Parasites in Antarctic krill guts inferred from DNA sequences. Antarct Sci. https://doi.org/10.1017/S0954102018000469

Cottier F, Tverberg V, Inall M, Svendsen H, Nilsen F, Griffiths C (2005) Water mass modification in an Arctic fjord through cross-shelf exchange: the seasonal hydrography of Kongsfjorden, Svalbard. J Geophys Res: Oceans. https://doi.org/10.1029/2004JC002757

Cottier F, Steele M, Nilsen F (2016) Sea ice and Arctic Ocean oceanography. In: Thomas DN (ed) Sea ice, 3rd edn. Wiley, Chichester, pp 197-215

Deja K, Węsławski JM, Borszcz T, Włodarska-Kowalczuk M, Kukliński P, Bałazy P, Kwiatkowska P (2016) Recent distribution of Echinodermata species in Spitsbergen coastal waters. Pol Polar Res. https://doi.org/10.1515/popore-2016-0027

Dilling L, Wilson J, Steinberg D, Alldredge A (1998) Feeding by the euphausiid Euphausia pacifica and the copepod Calanus pacificus on marine snow. Mar Ecol Prog Ser 170:189-201

Drewnik A, Węsławski JM, Włodarska-Kowalczuk M, Łącka M, Promińska A, Zaborska A, Gluchowska M (2016) From the worm's point of view. I. Environmental settings of benthic ecosystems in Arctic fjord (Hornsund, Spitsbergen). Polar Biol. https://doi.org/10.1007/s00300-015-1867-9

Eiane K, Daase M (2002) Observations of mass mortality of Themisto libellula (Amphipoda, Hyperidae). Polar Biol. https ://doi.org/10.1007/s00300-002-0361-3

Everson I (2000) Krill: biology, ecology and fisheries. Blackwell Science Ltd, Oxford

Fuentes V, Alurralde G, Meyer B, Aguirre GE, Canepa A, Wölfl AC, Hass C, Williams GN, Schloss IR (2016) Glacial melting: an overlooked threat to Antarctic krill. Sci Rep. https://doi. org/10.1038/srep27234

Gómez-Gutiérrez J, Robinson CJ (2006) Tidal current transport of epibenthic swarms of the euphausiid Nyctiphanes simplex in a shallow, subtropical bay on Baja California peninsula, México. Mar Ecol Prog Ser. https://doi.org/10.3354/meps320215

Gómez-Gutiérrez J, Peterson WT, De Robertis A, Brodeur RD (2003) Mass mortality of krill caused by parasitoid ciliates. Science. https://doi.org/10.1126/science.1085164

Gómez-Gutiérrez J, Morales-Avila JR, Kawaguchi S (2017) Krill-Parasite interactions. In: Global diversity and ecological function of parasites of euphausiids. Springer, Cham, pp 17-38

Goszczko I, Ingvaldsen RB, Onarheim IH (2018) Wind-driven crossshelf exchange-West Spitsbergen Current as a source of heat and salt for the adjacent shelf in Arctic winters. J Geophys ResOceans. https://doi.org/10.1002/2017JC013553

Greene CH, Wiebe PH, Burczynski J, Youngbluth MJ (1988) Acoustical detection of high-hensity krill demersal layers in the submarine canyons off Georges Bank. Science. https://doi. org/10.1126/science.241.4863.359

Gutt J, Siegel V (1994) Benthopelagic aggregations of krill (Euphausia superba) on the deeper shelf of the Weddell Sea (Antarctic). Deep-Sea Res I. https://doi.org/10.1016/0967-0637(94)90031-0

Hernando M, Schloss IR, Malanga G, Almandoz GO, Ferreyra GA, Aguiar MB, Puntarulo S (2015) Effects of salinity changes on coastal Antarctic phytoplankton physiology and assemblage composition. J Exp Mar Biol Ecol. https://doi.org/10.1016/j. jembe.2015.02.012

Hirai J, Jones D (2012) The temporal and spatial distribution of krill (Meganyctiphanes norvegica) at the deep seabed of the Faroe-Shetland Channel, UK: a potential mechanism for rapid carbon flux to deep sea communities. Mar Biol Res. https://doi. org/10.1080/17451000.2011.594891

Hirche HJ, Muyakshin S, Klages M, Auel H (2006) Aggregation of the Arctic copepod Calanus hyperboreus over the ocean floor of the Greenland Sea. Deep-Sea Res I. https://doi.org/10.1016/j. dsr.2005.08.005

Hirche HJ, Laudien J, Buchholz F (2016) Near-bottom zooplankton aggregations in Kongsfjorden: implications for pelagobenthic coupling. Polar Biol. https://doi.org/10.1007/s0030 0-015-1799-4

Jakacki J, Przyborska A, Kosecki S, Sundford A, Albretsen J (2017) Modelling of the Svalbard fjord Hornsund. Oceanologia. https:// doi.org/10.1016/J.OCEANO.2017.04.004 
Kaartvedt S, Røstad A, Fiksen Ø, Melle W, Torgersen T, Breien MT, Klevjer TA (2005) Piscivorous fish patrol krill swarms. Mar Ecol Prog Ser. https://doi.org/10.3354/meps299001

Kalinowski J, Witek Z (1980) Diurnal vertical distribution of krill aggregations in the West Antarctic. Pol Polar Res. 1:127-146

Laudien J, Orchard JB (2012) The significance of depth and substratum incline for the structure of a hard bottom sublittoral community in glacial Kongsfjorden (Svalbard, Arctic) — an underwater imagery approach. Polar Biol. https://doi.org/10.1007/s00300-011-1153-4

Legeżyńska J, Węsławski JM, Presler P (2000) Benthic scavengers collected by baited traps in the high Arctic. Polar Biol. https:// doi.org/10.1007/s003000000118

Lewis AG, Syvitski JPM (1983) The interaction of plankton and suspended sediment in fjords. Sediment Geol. https://doi. org/10.1016/0037-0738(83)90003-9

Lydersen C, Assmy P, Falk-Petersen S, Kohler J, Kovacs KM, Reigstad M, Steen H, Strøm H, Sundfjord A, Varpe $\varnothing$, Walczowski W, Weslawski JM, Zajaczkowski M (2014) The importance of tidewater glaciers for marine mammals and seabirds in Svalbard, Norway. J Mar Syst. https://doi.org/10.1016/j.jmarsys.2013.09.006

Lynn DH, Gómez-Gutiérrez J, Strüder-Kypke MC, Shaw CT (2014) Ciliate species diversity and host-parasitoid codiversification in the apostome genus Pseudocollinia (Ciliophora, Apostomatia, Pseudocolliniidae) that infect krill, with description of Pseudocollinia similis $\mathrm{n}$. sp., a parasitoid of the krill Thysanoessa spinifera. Dis Aquat Org 112:89-102

Mauchline J, Fisher LR (1969) The biology of euphausiids. Academic Press, London

Michaels AF, Silver MW, Gowing MM, Knauer GA (1990) Cryptic zooplankton "swimmers" in upper ocean sediment traps. Deep Sea Res A. https://doi.org/10.1016/0198-0149(90)90043-U

Miller DGM, Hampton I (1990) The biology and ecology of the Antarctic krill Euphausia superba Dana. Polar Biol. https://doi. org/10.1007/BF00233695

Nakagawa Y, Ota T, Endo Y, Taki K, Sugisaki H (2004) Importance of ciliates as prey of the euphausiid Euphausia pacifica in the NW North Pacific. Mar Ecol Prog Ser. https://doi.org/10.3354/ meps271261

Nicol S, Brierley AS (2010) Through a glass less darkly-new approaches for studying the distribution, abundance and biology of Euphausiids. Deep Sea Res II. https://doi.org/10.1016/j. dsr2.2009.10.002

Promińska A, Cisek M, Walczowski W (2017) Kongsfjorden and Hornsund hydrography - comparative study based on a multiyear survey in fjords of west Spitsbergen. Oceanologia. https:// doi.org/10.1016/j.oceano.2017.07.003

Ritz DA, Hosie GW, Kirkwood RJ (1990) Diet of Nyctiphanes australis Sars (Crustacea: Euphansiacea). Mar Freshw Res. https://doi. org/10.1071/MF9900365

Ryer CH, Stoner AW, Titgen RH (2004) Behavioral mechanisms underlying the refuge value of benthic habitat structure for two flatfishes with differing anti-predator strategies. Mar Ecol Prog Ser. https:// doi.org/10.3354/meps268231

Schmidt K, Atkinson A, Steigenberger S, Fielding S, Lindsay MCM, Pond DW, Tarling GA, Klevjer TA, Allen CS, Nicol S, Achterberg
EP (2011) Seabed foraging by Antarctic krill: implications for stock assessment, bentho-pelagic coupling, and the vertical transfer of iron. Limnol Oceanogr. https://doi.org/10.4319/ lo.2011.56.4.1411

Simard Y, Harvey M (2010) Predation on Northern Krill (Meganyctiphanes norvegica Sars). Adv Mar Biol. https://doi.org/10.1016/ B978-0-12-381308-4.00010-8

Sokolova MN (1994) Euphausiid "dead body rain" as a source of food for abyssal benthos. Deep Sea Res I. https://doi.org/10.1016/09670637(94)90052-3

Szczucka J, Hoppe Ł, Schmidt B, Fey DP (2017) Acoustical estimation of fish distribution and abundance in two Spitsbergen fjords. Oceanologia. https://doi.org/10.1016/j.oceano.2017.04.007

Thrush SF, Hewitt JE, Norkko A, Nicholls PE, Funnell GA, Ellis J (2003) Habitat change in estuaries: predicting broad-scale responses of intertidal macrofauna to sediment mud content. Mar Ecol Prog Ser. https://doi.org/10.3354/meps263101

Urbanski JA, Stempniewicz L, Wẹsławski JM, Dragańska-Deja K, Wochna A, Goc M, Iliszko L (2017) Subglacial discharges create fluctuating foraging hotspots for sea birds in tidewater glacier bays. Sci Rep. https://doi.org/10.1038/srep43999

Verity PG, Smetacek V (1996) Organism life cycle, predation, and the structure of marine pelagic ecosystems. Mar Ecol Prog Ser. https ://doi.org/10.3354/meps130277

Wakeham SG, Hedges JI, Lee C, Pease TK (1993) Effects of poisons and preservatives on the composition of organic matter in a sediment trap experiment. J Mar Res. https://doi.org/10.1357/00222 40933224043

Walkusz W, Kwasniewski S, Falk-Petersen S, Hop H, Tverberg V, Wieczorek P, Weslawski JM (2009) Seasonal and spatial changes in the zooplankton community of Kongsfjorden, Svalbard. Polar Res. https://doi.org/10.1111/j.1751-8369.2009.00107.x

Węsławski JM, Legeżyńska J (1998) Glaciers caused zooplankton mortality? J Plankton Res. https://doi.org/10.1093/plankt/20.7.1233

Węsławski JM, Koszteyn J, Zajączkowski M, Wiktor JM, Kwasniewski S (1995) Freshwater in Svalbard fjord ecosystems. In: Skjoldal H, Hopkins C, Erikstad K, Leinaas H (eds) Ecology of fjords and coastal waters. Elsevier, New York, pp 229-241

Węsławski JM, Pedersen G, Petersen SF, Poraziński K (2000) Entrapment of macroplankton in an Arctic fjord basin, Kongsfjorden, Svalbard. Oceanologia 42(1):57-69

Węsławski JM, Buchholz F, Głuchowska M, Weydmann A (2017) Ecosystem maturation follows the warming of the Arctic fjords. Oceanologia 59(4):592-602

Wishner KF (1980) The biomass of the deep-sea benthopelagic plankton. Deep Sea Res A. https://doi.org/10.1016/01980149(80)90012-6

Zajaczkowski M (2008) Sediment supply and fluxes in glacial and outwash fjords, Kongsfjorden and Adventfjorden Svalbard. Pol Polar Res 29:59-72

Publisher's Note Springer Nature remains neutral with regard to jurisdictional claims in published maps and institutional affiliations. 